Egypt. Acad. J. biolog. Sci., 1 (1): 1-6 (2010)

Email: egyptianacademic@yahoo.com

Received: 21/6/2010
D. Histology \& Histochemistry

ISSN: $2090-0775$

www.eajbs.eg.net

\title{
Histopathological alteration in the ovaries of the desert locust Schistocerca gregaria (Forskal) induced by the IGR consult and Lufox
}

\author{
Reda, F.A. Bakr ${ }^{1}$; Mona, I. Mohammed ${ }^{1}$; Abd Elazeem, M. El-Gammal. ${ }^{2}$ and \\ Noura, M. Mahdy ${ }^{2}$ \\ 1- Department of Entomology - Faculty of Science, Ain-Shams University \\ 2-Plant Protection Research Institute, Agric. Res. Center
}

\section{ABSTRACT}

Histopathological changes in the ovaries were tested in normal adult females and those developed from treated one day old of the fifth nymphal instar of the desert locust with $\left(\mathrm{LC}_{50}\right)$ of Consult and Lufox.

S. gregaria as well as other orthopterous insects has panoistic ovarioles, each ovariole is divided into a germarium and a vitellarium; the gemarium contains the oogonia and the pre-follicular cells which surround the oocytes to form the ovarian follicles in the vitellarium; and is invested with non-cellular tunica propria and an outer cellular sheath (tunica externa).

In the ovarian follicles of those females developed from the treated nymphs with consult showed vacuolization of cytoplasm and degeneration of the cell components of follicular epithelium, oocytes were the most obvious signs of damage.

Damage was pronounced in the ovarioles of these females developed from the treated nymphs with Lufox. Ovariole growth was stunted and vitellogenesis and chorion formation were completely inhibited.

Keywords: Locust, Schistocerca gregaria, ovaries, Histopathology, IGR (Consult-Lufox).

\section{INTRODUCTION}

Plagues of desert locust, Schistocerca gregaria (Forskal) have been recognized as a threat to agricultural production in Africa and western Asia for thousands of years.

IGRs are diverse groups of chemical compounds that are highly active against immature stage of insects and have a good margin of safety to most non-target biota including invertebrates, fishes, birds and other wild life, they are also safe to man domestic animals, they will play an important role in control programs in the future (Mulla, 1995).

The main types of insect growth regulators used commercially are juvenile hormone analogues and chitin synthesis inhibitors (Parrella and Murphy, 1998).

Histological studies of gonads may provide morphological evidence for functions of gonial, extragonial tissues and cells.

The aim of the present study is to examine the histopathological changes occurred in the ovaries of the female $S$. gregaria developed from treated one day old of the $5^{\text {th }}$ nymphal instar with sublethal concentration $\left(\mathrm{LC}_{50}\right)$ of two compounds of insect growth regulators; Consult (chitin synthesis inhibitor) and Lufox (mixture of juvenile hormone mimic and chitin synthesis inhibitor). 


\section{MATERIAL AND METHEDS}

\section{1-Origin of population}

The stock colony of Schistocerca gregaria was maintained for several years at the Luocst Research Division. Plant Protection Research Instiute, Agricultural Research Center, Dokki, Giza. The insects were reared and handled under the following technique described by Abbassi et al. (2003). Leaves of leguminous plant, Medicago sativa were daily placed as feeding material. The cages were incubated in a constant room temperature $\left(32 \pm 2^{\circ} \mathrm{C}\right)$ and $(30-50 \mathrm{RH})$.

\section{2- Insect growth regulators used}

Two analogues of insect growth regulators (IGRs) were used:

2-1. Hexaflumuron (10\% EC) (Chitin synthesis inhibitor):

Consult (Hexaflumuron), [N(((3,5-dichloro-4-(1,1,2,2-tetrafluroethoxy) phenyl)amino) carbonyl)-2,6- difluroben-zamide].

2-2. Lufox: mixture of juvenile hormone mimic (Fenoxycarb 7.5\% EC), ethyl [ 2-(4phenoxyphenoxy) ethyl] carbamate and Chitin Synthesis inhibitor (Lufenuron), (Axor $3 \% \quad$ EC). N-[[[ 2,5-dicholoro-4-(1,1,2,3,3,3-hexafluoropropxy) pheny] amino] carbonyl] -2,6-difluorobenzamide.

Consult and Lufox have proved to be toxic to one day old of the $5^{\text {th }}$ nymphal instor S. gregaria. (Bakr et al., 2009).

\section{3- Experimental insects:}

The First day of the $5^{\text {th }}$ nymphal instar of S. gregaria was treated with the estimated $\mathrm{LC}_{50}$ of Consult and Lufox. The living indiviuals completed the development to be adults were studied as the treated generation. The ovaries of the tenth day of females were dissected.

These ovaries were used for histological study by the light microscope

\section{4- Light microscop studies:}

The adult females were dissected out in Ringer's solution. The female reproductive organs were isolated from the freshly dissected insects.

Bouin's fluid was used to fix the female reproductive organs. The latter were then dehydrated in series of ethanol. Then cleared in xylene and embedded in paraffin wax. Serial sections, 5-7 $\mu \mathrm{m}$ were stained with haematoxylin and eosin, then cleared mounted in DPX.

\section{RESULTS AND DISCUSSION}

\section{A) Ovary of normal female:}

The female reproductive system consists of a pair of ovaries, which connect with a pair of lateral oviducts. These joint to form a medium common oviduct opening into a genital chamber where a spermatheca is opening for the storage of sperms.

Each ovary consists of a number of panoistic ovariole, where the developed of the oocytes take place. Each ovariole has a wall, which is made up of two layers; an outer ovariole sheath or tunica externa (cellular network) and inner tunica propria (elastic membrane).

\section{B) Structure of ovariol of normal female:}

The ovarian follicle of previtellogenic female ovariol is composed of one oocyte and an outer follicular epithelial layer. The oocyte has large germinal vesicle Fig. 1(a). The ovarian follicle is enclosed by one layer of follicular epithedial cells Fig.1 (b). 


\section{C) Histopathological studies:}

The histopathological investigation of ovarioles of female S. gregaria showed different deterioration effect after the treatment of 1 - day old of the $5^{\text {th }}$ nymphal instar by Consult and Lufox.

The structure of the previtellogenic ovarian follicles of adult female produced from treated nymphs with Consult has abnormal appearance Fig. (2). Wide spread cytolysis is observed in the follicle. The oocyte can not be identifief. The cytoplasm degenerated and vacuolated Fig. (2).

The treatment of the $5^{\text {th }}$ nymphal instar of $S$. gregaria with Lufox, showed malformed adult. The ovariole follicle are occupied by previtellogenic oocytes but no vitellogenic oocytes could be distinguished in any of the examined ovariole Fig. (3). The follicular epithelial cells are greatly malformed and lysis of cytoplasm are observed Fig. (3).

The present study has revealed many histopathological changes in ovaries of ten day old adult females produced of treated one day old of the $5^{\text {th }}$ nymphal instaar with Consult and Lufox each at $\mathrm{LC}_{50}$ induced disturbance in protein synthesis of the ovary which reflect an inhibition of ovary maturation.

From the present observations, it is evident that, the follicular cells are suffering from degeneration and vaculation. Follicular cells apparently regulate transfer of materials for oocyte growth. Histochemical studies on the telotrophic ovarioles of Crynodes peregrinus showed that follicle cells synthesize RNA which is exported to oocytes during its early stages of growth (Ray and Ramamurty, 1979).

These findings are similar to those observed by (Lim and Lee, 1982) who reported that diflubenzuron (DFB) retard the maturation of oocytes when applied against grasshopper, Oxya japanice. Also, Davey et al. (1993) recorded that the follicular epithdium surrounding the vitellogenic oocytes of Locusta migratoria, devdoped large spaces between the cells when ovary was exposed to methoprene.

Also, Tanaka et al. (1998). Applied juvenile hormone analogue, methoprene to Locusta migratoria and they found stimulated oocytes develoment in reproductively inactive females, while Zhang and Qi (2008) applied fenoxycarb against the newly emerged adults of xenopsylla cheopis, they found that the ovarian cells became atrophied.

\section{REFERENCES}

Abbassi, K.; Zineb, A. and Ghaout, S. (2003). Biological effects of alkaloids extracted from three plants of Moroccan avid areas on the desert locust. J. Physiologica; Entomol., 28: 232-236.

Bakr, R.F.A..; Mohammed M. I ; El-Gammal A . M.. and Mahdy N. M. (2009). Biochemical changes of the Chitin-synthesis inhibitor, Hexaflumuron (Consult) compound on the desert locust, Schistocerca gregaria (Forskal). Egypt. Acad. J. biolog. Sci., (Toxicology )1 (1): $59-68$

Davey, K. J.; Sevala, V.L. and Gordon, D.R.B. (1993). The action of juvenile hormone and antigonadotropic on the follicle cells of Locusta migratoria. Invert. Repord. Develop., 24(1): 39-45.

Lim, S. J. and Lee, S. S. (1982). Toxicity of diflubenzuron to the grasshopper, Oxya japonica: Effects on reproduction. Entomol. Exper. Et Applic., 31(2): 154168. 
Mulla, M. S. (1995). The future of insect growth regulators in vector control. J. Am. Mosq. Control. Assoc., 11(2): 269-273.

Parrella, M. P. and Murphy, B. C. (1998). Insect growth regulators. Growers Talke, 62(2): 86-89.

Rey, A. and Ramamurty, P. S. (1979). Source of RNA Supply to oocytes in Crynodes peregrinus fuessly (Coleoptera, chrysomedidac). Int. J. Insect Morphol. and Embryol.Vol. 8(2): 113-122.

Tanaka, S.; Okuda,T; Hasegwa, E. and Knon, Y. (1998). Suppression of oocyte development by a trehalase inhibitor, validoxylamine A, through inhibition of juvenile hormone biosynthesis and vitellogensis in the migratory locust. Locusta migratoria. Entomol. Sci., 13(3): 313-320.

Zhang, Y. C. And Qi, Y. M. (2008). Histological effect of fenoxycarb on the Oriental rat flea, Xenopsylla cheopis (Siphonaptera: Pulicidae). Acta Entomol. Sinica, 51(5):504-508. 


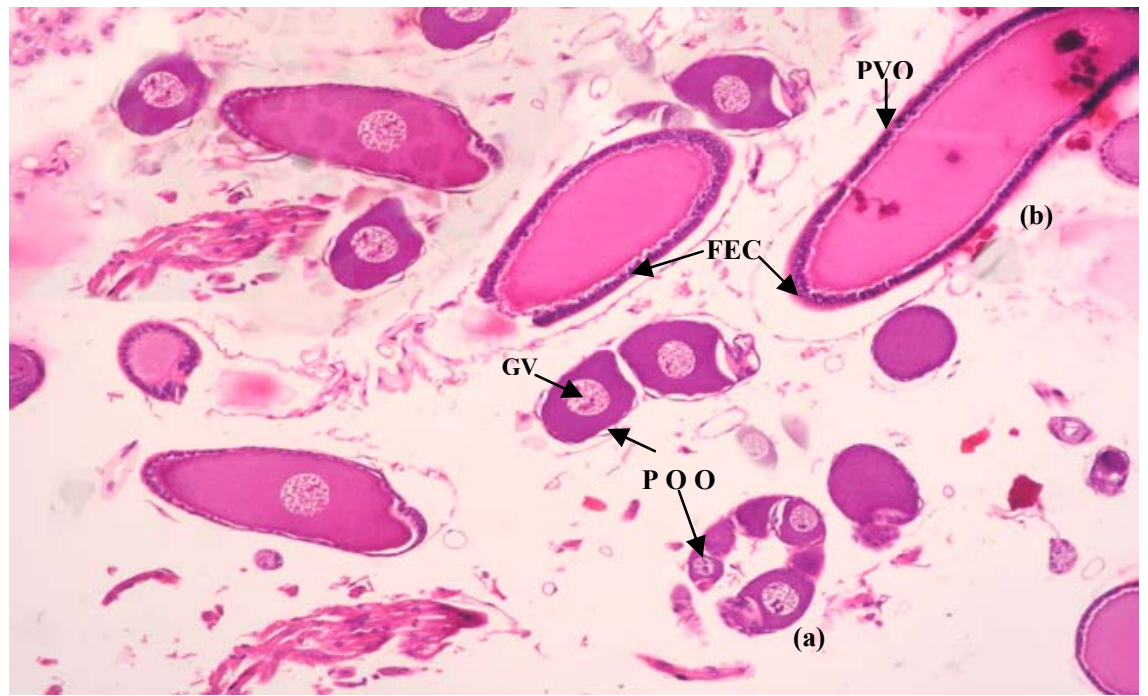

Fig. 1: Light micrograph of longitudinal section of ovary of normal female desert locust, Schistocerca gregaria shown different stages of immature oocytes. Notice primary oocyte (POO), previtellgenic oocyte (PVO), follicular epithelial cells (FEC), germinal vesicle (GV). (H\&E, x100)

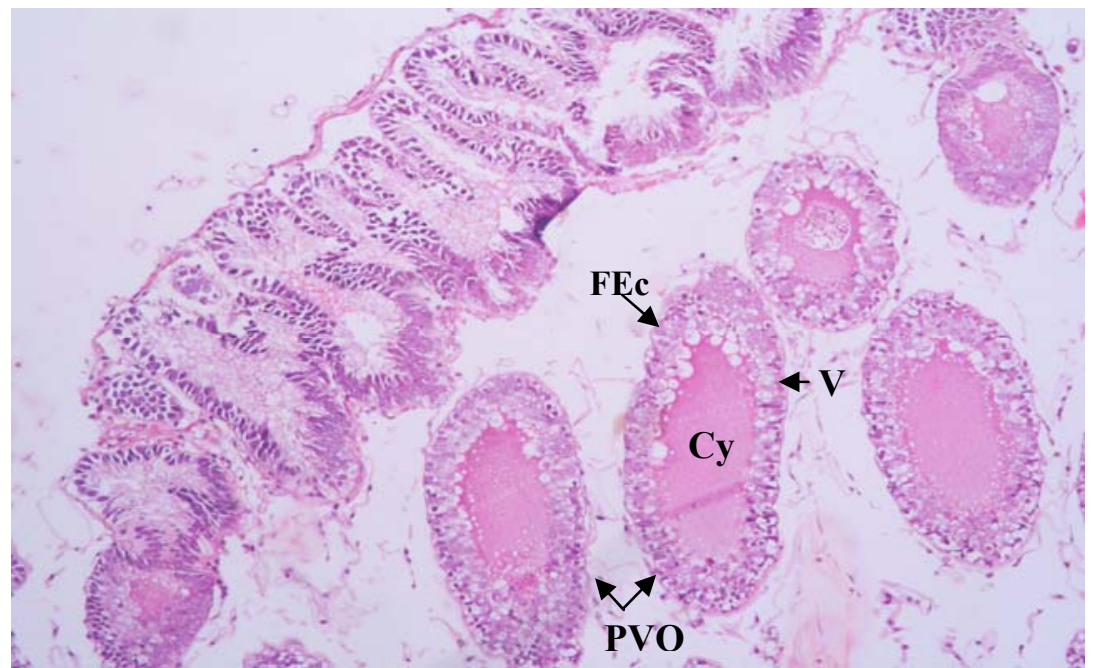

Fig. 2: Light micrograph of longitudinal section of ovary of normal female desert locust, Schistocerca gregaria developed from treated 1 day old of the $5^{\text {th }}$ nymphal instar with $\mathrm{LC}_{50}$ of consult shown previtellogenic oocytes (PVO), vacuoles (V) in follicular epithelial cells (FEC) and cytoplasm . (H\&E, X 200).

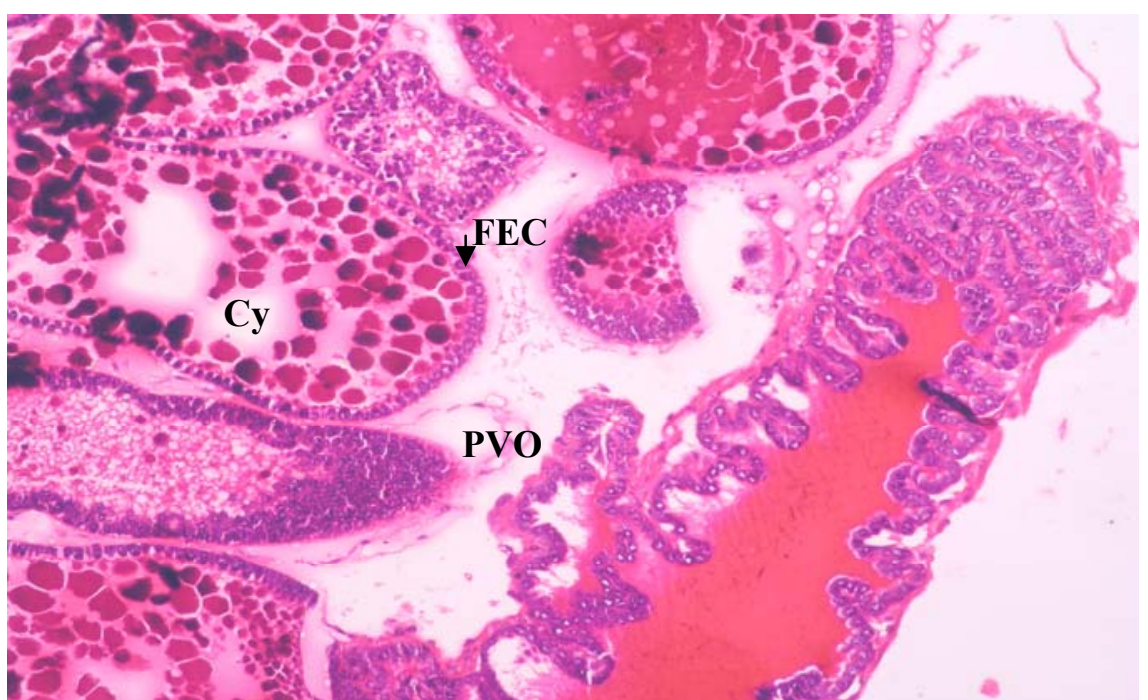

Fig. 3: Light micrograph of longitudinal section of ovary of normal female desert locust, Schistocerca gregaria developed from treated 1 day old of the $5^{\text {th }}$ nymphal instar with $\mathrm{LC}_{90}$ of lufox shown malformed previtellogenic oocvtes (PVO). follicular enithelial cells (FEC) and cvtoplasm (CY). 


\section{ARABIC SUMMARY}

التغيرات النسيجية فى مبيض الجراد الصحراوى شيستوسيركا جريجاريا الناتجة من منظمات النمو الحشرية

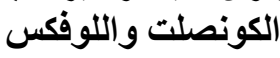

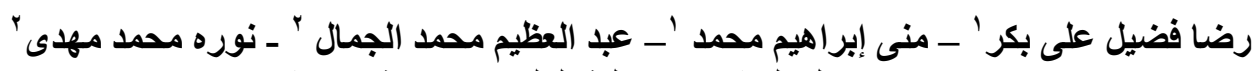

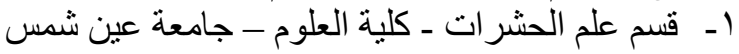

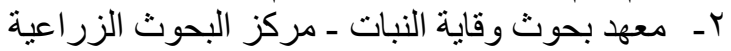

تم در اسة التغيرات النسيجية فى مبايض الطور اليافع للجر اد الصحر اوى بعد عشر أيسام من انسـلاخها من

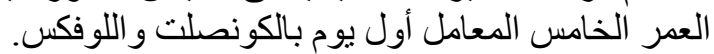

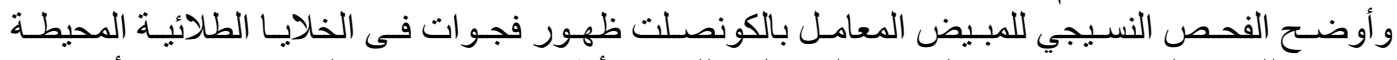

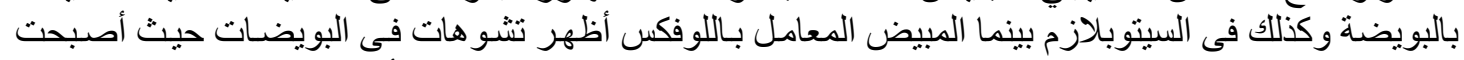
ممتلئة بتشققات من السيتو بلازم وكذلك نشوه فى الخلايا الطلائية المحيطة بها الفيث حيث أصبحت مدمج خلوي. 